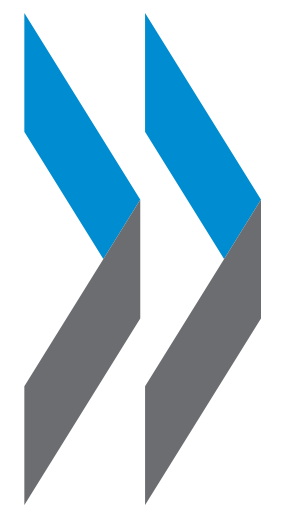

\title{
Towards Complete Balance Sheets in the National Accounts
}

THE CASE OF MINERAL AND ENERGY RESOURCES 



\section{OECD GREEN GROWTH PAPERS}

The OECD Green Growth Strategy, launched in May 2011, provides concrete recommendations and measurement tools to support countries' efforts to achieve economic growth and development, while at the same time ensuring that natural assets continue to provide the ecosystem services on which our well-being relies. The strategy proposes a flexible policy framework that can be tailored to different country circumstances and stages of development.

OECD Green Growth Papers should not be reported as representing the official views of the OECD or of its member countries. The opinions expressed and arguments employed are those of the author(s).

OECD Green Growth Papers aim to describe preliminary results or research in progress by the author(s) and are published to stimulate discussion on specific topics and obtain feedback from interested audiences.

They complement the OECD Green Growth Studies series, which aims to provide in-depth reviews of the green growth issues faced by different sectors.

This paper has been authorised for publication by Martine Durand, Director of the OECD Statistics Directorate. This paper reflects the view of the authors and not necessarily those of the OECD or its Member Countries. The paper was presented at the Conference of the Society for Economic Measurement in Chicago (August 2014) and the meeting of the Strategic Forum in Rome (September 2014). The authors thank participants at these events and Pierre-Alain Pionnier (OECD) for helpful comments. All errors remain their own.

Comments on Green Growth Papers are welcomed, and may be sent to:

OECD Green Growth Unit, 2, rue André Pascal, 75775 PARIS CEDEX 16, France or by email to greengrowth@oecd.org.

OECD Green Growth Papers are published on: www.oecd.org/greengrowth

Please cite this paper as:

Schreyer, P. and Obst, C., (2015), "Towards Complete Balance Sheets in the National Accounts: The Case of Mineral and Energy Resources", OECD Green Growth Papers, No. 2015/02, OECD Publishing, Paris. DOI:

\section{(C) OECD (2015)}

You can copy, download or print OECD content for your own use, and you can include excerpts from OECD publications, databases and multimedia products in your own documents, presentations, blogs, websites and teaching materials, provided that suitable acknowledgment of OECD as source and copyright owner is given.

All requests for commercial use and translation rights should be submitted to rights@oecd.org 
TABLE OF CONTENTS

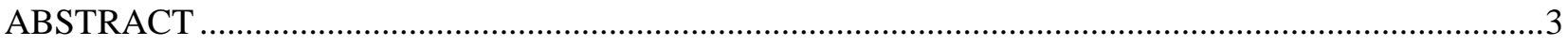

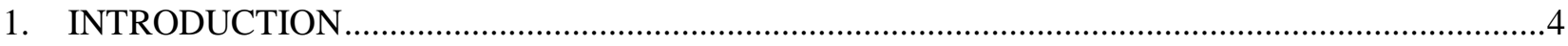

2. THE SCOPE OF ASSETS IN THE SNA AND SEEA BALANCE SHEETS ….....................................

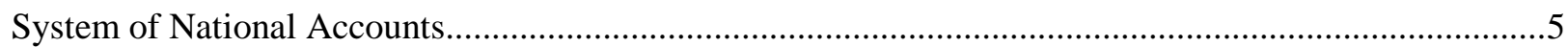

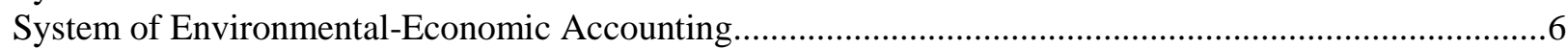

3. VALUING THE NATURAL RESOURCE STOCK ……................................................................

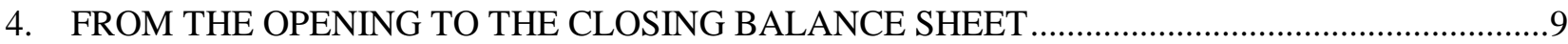

5. USING BALANCE SHEET DATA - A VOLUME INDEX OF THE STOCK OF NATURAL

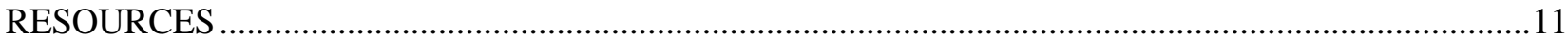

6. APPLICATION TO AUSTRALIAN DATA: VOLUME INDEX OF MINERAL AND ENERGY

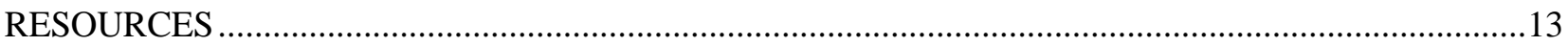

7. BEYOND THE NATIONAL ACCOUNTS - MEASURING SUSTAINABILITY .............................18

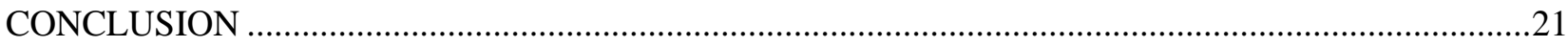

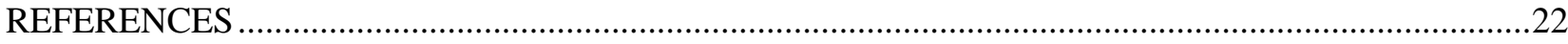




\begin{abstract}
Despite its importance, regular measurement of the value of natural resources at national level is still in its infancy and often disconnected from valuation approaches for other assets. We show that there exists a consistent approach towards valuation that applies to subsoil assets and produced capital alike. We further align accounting in physical and monetary terms and construct standard volume and price indexes of energy and mineral resources with an application to Australia. Finally, we examine the link between our measure of subsoil wealth and indicators of sustainability. Overall, this paper demonstrates how the bodies of work on capital theory, index number measurement and growth accounting on the one hand, and valuation and measurement of natural resources on the other can be aligned. From a practical accounting perspective this alignment should aid in the implementation of broader measures of wealth at national level which are required for policy and analysis.
\end{abstract}

\title{
RÉSUMÉ
}

En dépit de leur importance dans l'estimation des richesses d'un pays, les ressources naturelles commencent à peine à être prises en compte de façon systématique et sont bien souvent évaluées indépendamment des autres actifs.

Dans ce rapport, nous verrons qu'il existe une approche cohérente pouvant s'appliquer aussi bien à l'évaluation des richesses du sous-sol qu'à celles du capital produit. Nous combinerons comptabilités physique et monétaire et définirons un indice des prix et du volume de l'énergie et des ressources naturelles avec une application à l'Australie. Enfin, nous examinerons le lien entre notre mesure des richesses du sous-sol et les indicateurs de développement durable. Nous démontrerons qu'il est possible d'aligner, d'un côté, les travaux sur la théorie du capital, la mesure des indices et la comptabilité de la croissance et, de l'autre, la valorisation et la mesure des ressources naturelles. Concrètement, cet alignement devrait permettre de mesurer plus précisément l'étendue des richesses au niveau national, et donc offrir une meilleure analyse servant de base aux politiques mises en place. 


\section{INTRODUCTION}

In official government statistics, the measurement of wealth has been overshadowed by work on the measurement of economic growth, changes in prices and employment. Consequently, analysis of the well established theoretical links between wealth and the sustainability of economic growth, and well-being more generally (Stiglitz et al. 2009, OECD 2011, 2013) have not been supported by well established, national data sets. Instead, at national level, measures of wealth are generally more piece-meal with various information on the stock of produced assets (buildings, machines, etc), the value of financial assets and liabilities and some information on the value of land. Only a few countries release complete balance sheets including information on natural resources and even fewer have made attempts to develop estimates of all environmental assets, and human and social capital.

As consideration of the issues of sustainability grows increasingly important, this lack of information on the components of national wealth is of serious concern. Over the past decade, the World Bank has taken a leading role in developing broad measures of national wealth (World Bank, 2011). Also at an international level, the international standards for national accounting, the System of National Accounts 2008 (SNA), describe national balance sheets incorporating all economic assets. Under the leadership of the OECD, work is underway to support the development of such balance sheets in a wider number of countries. Most recently, the adoption by the United Nations Statistical Commission in February 2012 of the System of Environmental-Economic Accounting 2012 Central Framework (SEEA Central Framework) has placed a clear focus on the measurement of environmental assets and natural resources.

For the measurement of national wealth and the construction of national balance sheets it is important to apply integrated definitions and measurement boundaries for the different assets and also consistent valuation concepts. In both theory and practice, this is a challenging exercise. One focus in this paper is to describe the approach to the valuation of natural resources and their depletion that has been developed for the SEEA Central Framework. It differs from many commonly used techniques but is based on wellestablished capital theory and, importantly, is symmetric to the established valuation approaches for produced assets that are found in the SNA and in productivity measurement.

A second focus of the paper is the application of the valuation approach to the development of a consistent and complementary index of the volume of natural resources. We develop a measure for Australia. While the paper does not extend the approach beyond sub-soil, mineral and energy resources, the logic can be applied more generally to all individual environmental assets. We demonstrate that, as prices of mineral and energy resources tend to be subject to significant fluctuations, the choice of index number formulae for the volume index is of great importance.

Application of our approach to the valuation of ecosystems, to human capital and other forms of capital is yet to be developed. At the same time work on the valuation of ecosystems in a national accounting context is advancing (see United Nations et al 2013) and work on the valuation of human capital has a strong history (see Jorgenson and Fraumeni, 1989). While much work remains to fully integrate capital valuations, it is important for the mainstreaming of the discussion of wealth and sustainability that robust, consistent, practical and widely agreed measurement concepts and approaches are found and applied across countries. This paper provides a step in that direction. 


\section{THE SCOPE OF ASSETS IN THE SNA AND SEEA BALANCE SHEETS}

\section{System of National Accounts}

Our starting point is an overview of balance sheets as defined by the System of National Accounts 2008 (Table 1). Although nearly all OECD countries' national accounts have measures for some types of assets, few countries actually have measures for all types of economic assets as defined by the asset boundary of the SNA. Most frequently, measures of fixed assets and inventories exist, thus covering a vast part of produced assets. Similarly, data on financial assets and liabilities are readily available, typically by institutional sector and over extended periods of time. When it comes to non-financial, non-produced assets, the picture is much bleaker. Information on non-financial, non-produced assets tends to be absent from many balance sheets. Yet, these assets which include natural resources and land, are potentially very important items in a country's wealth ${ }^{1}$. We shall not discuss the measurement and valuation of land here which constitutes a topic in itself and simply refer to examples of ongoing work by Diewert and Shimizu (2013) and European Union (2011). Countries that are most advanced in the measurement of complete SNA balance sheets include Australia, France, the Netherlands and Korea.

Before discussing natural resources, it is useful to recall the dual nature of capital and the associated measures. It is well established in the literature on capital measurement (Jorgenson 1963, Jorgenson and Griliches 1967, Schreyer and Diewert 2008, OECD 2009) that non-financial capital is both a factor of production and a means of storing wealth. Each aspect of capital is associated with a particular measure:

- $\quad$ The wealth aspect of capital requires a measure that reflects the market value of capital. Measures of the wealth stock are the conceptually correct entry for balance sheets. The overall wealth stock (also called 'net stock' because the values are corrected for depreciation and retirement of assets) is the simple sum of different types of assets within a defined asset boundary, each valued at their market (i.e. replacement or second-hand) prices. Balance sheets relate to particular points in time. Between the opening and closing balance sheet, the change in the wealth stock can be decomposed into additions to the stock (such as investment in the case of produced assets or 'economic appearance' (such as viable discoveries in the case of non-produced assets) minus depreciation or depletion, plus holding gains or losses.

- The production aspect of capital requires a measure that reflects the flow of capital services into production. For produced assets, capital services are not normally observable and the assumption is made that they are proportional to the volume change of the net stock of the asset in question. Unlike the wealth stock, the price of each type of capital service is identified with user costs or rentals, designed to capture the marginal productivity of the different types of assets. For some non-financial, non-produced assets such as natural resources, the flow of capital services can be more readily observed and corresponds to the volume of extracted material that enters the production process. The input price in these cases is the unit resource rent for the extractor. Whether a produced or non-produced asset, the flow measure of capital services is the conceptually correct variable to capture the role of assets as factors of production.

\footnotetext{
${ }^{1}$ When all non-financial assets are summed and a deduction is made for net financial liabilities to the rest of the world, one obtains a measure of a country's net worth. Recent work on balance sheet data by Piketty and Zucman (2013) for several OECD countries has advanced our knowledge on total wealth as defined in the national accounts but much remains to be done. In addition, there are significant gaps in measures of wealth outside the SNA asset boundary.
} 
Despite the two distinct perspectives, the wealth and the production spheres are linked and so are its measures. Indeed, they should be constructed consistently and as part of an integrated framework as laid out for instance by the 2008 SNA or in more detail by OECD (2009) and Jorgenson, Landefeld and Nordhaus (2006). The rest of this paper focuses on the wealth sphere of natural resources although the link to the production sphere will remain apparent in discussing valuation ${ }^{2}$.

Table 1: A Stylised SNA Balance Sheet for the total economy

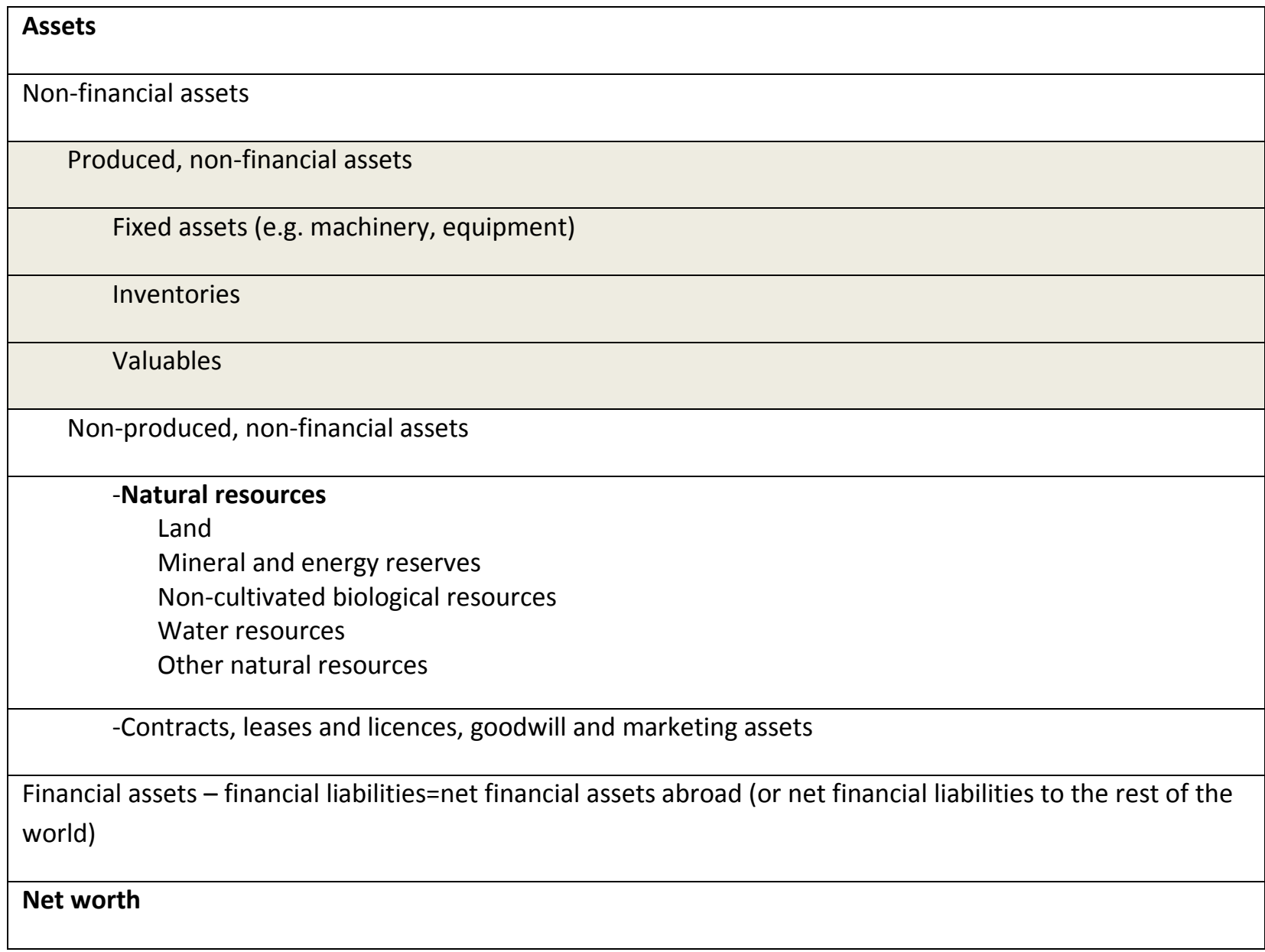

Source: SNA 2008.

\section{System of Environmental-Economic Accounting}

The increasing recognition of the strong relationship between economic activity and the environment has led to ongoing work within statistical circles to develop approaches to the integration of environmental information into the standard national accounts. The adoption of the System of Environmental-Economic Accounting 2012 Central Framework (SEEA Central Framework) by the United Nations Statistical Commission in 2012 represents a key milestone in this integration. The SEEA Central Framework is an

\footnotetext{
${ }^{2}$ See Brandt, Schreyer and Zipperer (2013) for a demonstration how natural resources can be incorporated into measures of production and productivity. Research has also advanced significantly on the measurement of volumes and prices of real estate and land, see in particular Diewert and Shimizu (2013), Diewert and Fox (2014) and European Union et al. (2011).
} 
international statistical standard providing greater clarity and motivation for countries to account for environmental stocks and flows on an ongoing basis.

An important aspect of the SEEA Central Framework is accounting for environmental assets. The SEEA's measurement boundary for environmental assets is defined in bio-physical terms as including all bio-physical components of a country including sub-soil mineral and energy resources, timber, fish, water, soil and land. These components of the asset boundary may also be considered from a perspective of ecosystems (e.g. timber, water and soil working together in a forest ecosystem asset) but the physical asset boundary is the same in both cases.

The physical asset boundary of the SEEA Central Framework encompasses all of the natural resources within the SNA but goes slightly further than the SNA by encouraging accounting for all environmental assets even if they have no current economic value. For example, all land within a country should be part of a physical asset account for land, not only land with economic value. Also, for sub-soil mineral and energy resources all known deposits are included not only those resources with current economic value as is the case in the SNA. However, in monetary terms, the SEEA Central Framework and the SNA have identical asset boundaries and hence, for the purposes of the discussion here, the SNA and the SEEA Central Framework approaches should be considered fully aligned.

\section{VALUING THE NATURAL RESOURCE STOCK}

The SNA and the SEEA Central Framework stipulate that the valuation of natural resources should be consistent with the valuation of produced assets. Ideally then, observable market prices should be used. One example for a valuation based, at least partially, on observed transactions is land (even if the value of land beneath structures is often hard to disentangle from the combined value of land and structures to which observable transactions relate - see for instance the work by Diewert and Shimizu 2013). For produced assets, in the absence of observed market prices, the most common approach is to use the written down replacement (or depreciated) value of the assets using data on investment expenditure and assumptions regarding asset lives and depreciation rates.

However, in the case of natural resources other than land, there is no relevant investment expenditure for the asset itself and there is usually little direct information on prices of the assets in the ground. It is essential that the price of the asset in the ground is distinguished from the prices of extracted resources, i.e., output prices received by the extraction industry that are more frequently available. When there are no observable prices for the asset, an attempt has to be made to estimate what the prices would be were the assets to be acquired on the market.

Consequently, the SNA and the SEEA Central Framework suggest valuing stocks of natural resources using the net present value (NPV) method. The NPV method rests on an assumption of asset market equilibrium that stipulates that the market value of an asset should equal the sum of discounted future income associated with the use of the asset. In the case of natural resources, expected income corresponds to the flow of discounted expected resource rents.

$p^{t} X^{t}=\sum_{\tau=0}^{\infty} R R^{t+\tau} /\left(1+r_{t}\right)^{\tau}$. 
Here, $p^{t}$ is the price per unit of the resource in the ground at the end of period $t, X^{t}$ is the stock of the resource in the ground at the end of period $t, R R^{t+\tau}$ is the expected resource rent in period $t+\tau . r_{t}$ is the discount rate as applied in period $t$ for all future income streams. The resource rent itself is the product of the sales price per extracted resource, $p_{S}^{t+\tau}$ net of extraction $\operatorname{costs}^{3}$ and the quantity $S^{t+\tau}$ of extracted resources sold in period $t+\tau$ :

$R R^{t+\tau}=p_{S}^{t+\tau} S^{t+\tau}$

We note that the extracted flow of resources $S^{t}$ represents the volume of capital services derived from a natural resource. Unlike produced assets, the flow of capital services is observable in the case of natural resources. Hence, there is no need to assume a constant proportion of capital service flows and asset stocks as is usual in productivity measurement (OECD 2009). Conversely, in the case of produced assets, the purchase price - conceptually equivalent to $p^{t}$ - is known unlike the situation for subsoil assets. Despite different empirical challenges, the underlying asset price model is the same and no separate theory is needed for natural and produced assets.

There are some limitations of market or near-market valuation of assets ${ }^{4}$ but a market valuation is consistent with the SEEA Central Framework and with the SNA, and thus offers the possibility of integrating results with measures of the stocks and flows of other assets on national balance sheets. It may be noted that without the use of a consistent valuation concept across all asset types, integration, aggregation and comparison across asset types (and with measures of flows such as operating surplus and value added) is not possible. The market, or perhaps better "exchange", value concept of the SEEA and the SNA provides an appropriate basis for integration that is not afforded by other valuation concepts, for example those that include consumer surplus.

The standard approach towards evaluating NPV requires three pieces of information: (i) an extraction profile $\left\{S^{t+\tau}\right\}_{\tau}$ as expected at time $t$; (ii) a profile for the expected unit resource rent of the extracted resource $\left\{p_{S}{ }^{t+\tau}\right\}_{\tau}$; and (iii) a discount rate $r$. These are then combined in a calculation following (1) . Selection of (i) - (iii) amounts to making price and extraction forecasts, along with the choice of a discount rate. This can be done in various ways but tends to be implemented using simplifying assumptions. For instance, in the absence of detailed information, the SEEA suggests using a constant rate of extraction or the most recent quantity of extraction as estimates of future production and to assume that unit resource rents follow a long-run historical trend or evolve in line with an expected general rate of inflation (SEEA

\footnotetext{
${ }^{3}$ This price net of extraction costs is equal to the unit resource rent. Note that extraction costs include the user costs of produced capital. For further indications about measuring the unit resource rent see also section 5.4.4. in the SEEA Central Framework.

${ }^{4}$ The computation of resource rents uses relies on market prices and market extraction costs, and consequently reflects a private rather than a social valuation of natural resources. The former only captures market returns to the owner or user of the asset, the latter would also reflect externalities arising with the extraction of natural resources. For several natural resources, it will be the case that the main benefits derived from them lie in their economic use. Hence, the difference between private and social valuation would be small. In other cases, there may be un-priced social "bads" associated with the extraction of such resources and with their use in the economy (e.g. climate change impacts). The discrepancy between private and social valuation is likely to be large in the case of soil, or timber as these natural assets are also parts of ecosystems such as forests whose benefits exceed the economic provisioning services that are provided by timber or the nutritional input from soil to agriculture.

${ }^{5}$ Landefeld and Hines (1985) apply direct NPV computations to U.S. data and discuss their limitations.
} 
§5.12 and A5.13). These simplified approaches have the benefit of being straight forward to implement and are easily replicable by data users ${ }^{6}$.

By shifting (1) by one period and multiplying through by $\left(1+r_{t}\right)$ an explicit expression is obtained for the resource rent or user cost:

$R R^{t}=p^{t-1} X^{t-1} r_{t}-\left(p^{t} X^{t}-p^{t-1} X^{t-1}\right)$

Expression (3) is the standard expression for the user costs of capital (Jorgenson 1963, Diewert 1974, OECD 2001, 2009) and it is apparent that resource rents comprise a return on capital (the first expression on the right hand side) and an element that captures the value change of the asset, itself composed of the value of depletion and revaluation as will be shown in the next section.

In the special and rather restrictive Hotelling (1931) case, the asset price change equals the nominal interest rate $\left(r=p^{t} / p^{t-1}-1\right)$ and equation (3) reduces to $R R^{t}=-p^{t} \Delta X^{t}$. Hence, in this case, the price of the asset in the ground, $p^{t}$, is set equal to the unit resource rent. While this shortcut towards valuing the unknown $p^{t}$ is regularly used in empirical work, it should be apparent that it rests on highly restrictive conditions as there is little evidence of natural resource prices and interest rates to follow the same profile (Livernois 2008). In addition, authors in the field have often labelled the Hotelling valuation as 'user costs'. While this is largely an issue of terminology, it wrongly suggests an equivalence to the established notion of user costs in (3).

\section{FROM THE OPENING TO THE CLOSING BALANCE SHEET}

The next task consists of valuing the changes in the natural resource stock over the accounting period. Starting with quantities, it is assumed that the quantity of natural resources at the end of period $t, X^{t}$ is known and that there is a projected sequence of extractions, and resource rents, based on the information available at the end of period $t$. Ex-post, the difference between $X^{t}$ and $X^{t-1}$ can be de-composed into three principal components: depletion, discoveries and catastrophic losses. Ex-ante, i.e. based on the information

\footnotetext{
${ }^{6}$ There is, however, a risk of inconsistency in price and production forecasts that tend to be considered independent. What is more, by projecting future prices and extraction quantities on the basis of very simple rules or the most recent observations, no use is made of the stochastic information available from the history of commodity prices. As commodity prices exhibit large swings, there is significant uncertainty about their future development. In a world where commodity prices are highly volatile, it does not seem reasonable to assume that markets and extracting firms take their decisions looking only at the current price or an average of recent realisations to project their expected values. From an accounting perspective, too simple a valuation method is not only a poor approximation to implicit market valuations but will also lead to highly volatile stock measures of the value of natural resources. The associated revaluation entries - to the extent that they do not capture market signals - may reduce the usefulness of stock-flow data and balance sheets. One way to improve on the simple deterministic approach is to acknowledge the stochastic nature of price developments and make full use of the information available from the distribution of prices when computing NPVs. A discussion of these matters is beyond the scope of the present paper.
} 
at the end of the preceding period $t-1$, discoveries and catastrophic losses $\left(D^{t}\right)$ will not be known. For the purpose at hand, we shall only consider the ex-post case $^{7}$ so that

$X^{t}-X^{t-1}=D^{t}-S^{t}$

The SEEA defines depletion as the regular and expected reductions from the stock of the asset, associated with the economic activity of extraction (and harvesting exceeding regeneration in the case of renewable resources). When there are catastrophic losses or discoveries, the aggregate physical change in stocks $\left(X^{t}-X^{t-1}\right)$ may be different from depletion.

Degradation must be distinguished from depletion. Degradation "considers changes in the capacity of environmental assets to deliver a broad range of ecosystem services and the extent to which this capacity may be reduced through the action of economic units" (SEEA Central Framework 5.90). Degradation is thus a broader concept than depletion and more complicated to measure. However, some aspects of degradation can be captured through sufficient differentiation of the natural resources under consideration and the measurement of depletion for each natural resource. For instance, by distinguishing between different types of soil quality (and treating each type as a distinct natural resource), a shift towards lowerquality soils will be captured as a volume change of the resource. From an alternative direction, in the case of a biological resource such as timber, environmental degradation could quite conceivably influence the value and volume of harvestable timber and hence be reflected in measures of the depletion of timber resources. $^{8}$

Ex-post, one possibility to decompose the change in value of the natural resource between the beginning and the end of period $t$, as follows:

$p^{t} X^{t}-p^{t-1} X^{t-1}=p^{t-1} \Delta X^{t}+X^{t} \Delta p^{t}$

In (3), noting that $\Delta X^{t} \equiv X^{t}-X^{t-1}$ and $\Delta p^{t} \equiv p^{t}-p^{t-1}$, then $p^{t-1} \Delta X^{t}$ and $X^{t} \Delta p^{t}$ constitute a quantity effect and a price or revaluation effect, respectively. There is an alternative way to de-compose the term $\left(p^{t} X^{t}-p^{t-1} X^{t-1}\right)$, namely with a quantity effect $p^{t} \Delta X^{t}$ and a revaluation effect $X^{t-1} \Delta P^{t}$. Neither decomposition is a-priori superior to the other, so we employ an arithmetic average ${ }^{9}$ of the two effects:

$$
\begin{aligned}
& p^{t} X^{t}-p^{t-1} X^{t-1}=\frac{1}{2}\left[\left(p^{t-1}+p^{t}\right) \Delta X^{t}+\left(X^{t-1}+X^{t}\right) \Delta p^{t}\right] \\
& =\frac{1}{2}\left[\left(p^{t-1}+p^{t}\right)\left(D^{t}-S^{t}\right)+\left(X^{t-1}+X^{t}\right) \Delta p^{t}\right]=\bar{p}^{t}\left(D^{t}-S^{t}\right)+\bar{X}^{t} \Delta p^{t}
\end{aligned}
$$

\footnotetext{
${ }^{7}$ Annex 5A of the SEEA Central Framework provides more detail in regards to the treatment of new information set between the beginning and the end of the accounting period. In the SEEA, discoveries constitute an unexpected addition to the natural resource during the accounting period. The SEEA also spells out which types of discoveries should be accounted for. For instance, in the case of mineral and energy resources, only new known deposits constitute discoveries. Catastrophic losses relate to unexpected and significant reductions in the natural resource during the period. They constitute exceptional and significant losses.

8 The measurement of degradation of ecosystems is discussed at some length in SEEA Experimental Ecosystem Accounting, Chapter 4 (UN et al. 2013) and also in Edens and Hein (2013).

${ }^{9}$ The use of an arithmetic average is only one of a number of options. In section 6 alternative averaging approaches reflecting different index number formulae are tested and compared.
} 
The arithmetic average in equation (6) is a Bennet (1920) decomposition whose properties and applications are discussed in depth ${ }^{10}$ by Diewert (2005) and Fox (2005). Valuation of extraction using the average price of the period is consistent with the rules in the SNA for the valuation of depreciation in the case of fixed assets. Also, discoveries (and catastrophic losses) are valued with mid-period prices of the resource "in the ground".

\section{USING BALANCE SHEET DATA - A VOLUME INDEX OF THE STOCK OF NATURAL RESOURCES}

We now employ part of the accounting framework above to develop a volume index of natural resources. For a single homogenous natural resource, the volume change of the resource can be expressed in physical units and corresponds to $\Delta X^{t}$ thus capturing additions to stock and removals from stock. For any stock $i=1,2, \ldots N$, the physical asset base is preserved if $X_{i}^{t}-X_{i}^{t-1} \geq 0$. With multiple assets, a common unit must be chosen to aggregate net changes of different types of assets. The common unit is obtained by weighting quantity changes using average prices $\bar{p}_{i}^{t}$ as outlined above ${ }^{11}$. Then, the asset base, valued at average prices is non-decreasing between the beginning and the end of an accounting period if

$\sum_{i} \bar{p}_{i}^{t}\left(X_{i}^{t}-X_{i}^{t-1}\right) \geq 0$.

It should be clear that the approach here defines sustainability in terms of maintenance of the aggregate volume of the asset base ${ }^{12}$. If all prices $\bar{p}_{i}^{t}$ were expressed in real terms (for instance after dividing through by a consumption price index), expression (7) could also be interpreted as requiring that the purchasing power of the asset base is maintained. It is also the case that the index implicitly reflects an assumption of weak sustainability, i.e., that an absolute decline in one type of resource can be compensated for by an increase in another of higher relative price.

The average rate of change in stocks is computed as the ratio between the value of change in stocks and the stock of assets at the beginning of the period valued at mid-period prices, $\sum_{i} \overline{p_{i}^{t}} X_{i}^{t-1}$ :

\footnotetext{
${ }^{10}$ Diewert (2005) explores the properties of bilateral Bennet-type decompositions. Fox (2005) extends the discussion to multilateral indices.

${ }^{11}$ Economic theory suggests for the purpose of assessing sustainability, the relevant price is a social price that reflects the marginal utility that society derives from keeping one unit of a particular asset intact (see for instance Dasgupta 2009). In a world of perfect information, such 'social accounting prices' would be known and they would reflect scarcities of natural resources along with the positive and negative effects that the exploitation of these resources has on society's present and future welfare. In a world of perfect markets, market prices of natural resource assets would contain all relevant information and they would equal social accounting prices. In the absence of perfect information and/or perfect markets, the quest for reasonable proxies to social accounting prices constitutes a significant task.

${ }^{12}$ Real and nominal price changes of assets, although they affect the level of wealth are in general excluded when monitoring sustainability as they do not affect long-run consumption possibilities, at least at the aggregate level and in closed economies. The literature on the treatment of holding gains and losses is large but Dasgupta (2009) is a good reference for an overview. Sefton and Weale (1996) deal with holding gains in an open economy context.
} 
$\frac{\sum_{i} \overline{p_{i}^{t}}\left(X_{i}^{t}-X_{i}^{t-1}\right)}{\sum_{i} \overline{p_{i}^{t}} X_{i}^{t-1}}=\frac{\sum_{i} \overline{p_{i}^{t}} X_{i}^{t-1}\left(\frac{X_{i}^{t}}{X_{i}^{t-1}}-1\right)}{\sum_{i} \overline{p_{i}^{t}} X_{i}^{t-1}}=\sum_{i} \frac{\bar{p}_{i}^{t} X_{i}^{t-1}}{\sum_{i} \overline{p_{i}^{t}} X_{i}^{t-1}} \frac{X_{i}^{t}}{X_{i}^{t-1}}-1$.

From (8) it is apparent that the average rate of change in stocks corresponds to a volume index (minus one) of natural resources. The quantity change of each asset is weighted by the share that this asset occupies in the total stock of assets at the beginning of the period, valued at mid-period prices. Mid-period valuation in the derivation of (8) is important as natural resource prices can vary significantly over an accounting period.

We shall label the volume index as $I^{t} \equiv \sum_{i} \frac{\bar{p}_{i}^{t} X_{i}^{t}}{\sum_{i} \bar{p}_{i}^{t} X_{i}^{t-1}}$ which is a Marshall-Edgeworth type volume index (Marshall 1887, Edgeworth 1925). Although not a superlative index, Diewert (1978, p897) showed that it will approximate any superlative index under certain regularity conditions. An alternative approach would have been to proceed with directly constructing a superlative index, such as the Fisher Ideal Index. The Fisher Ideal Index is a geometric average of a Laspeyres-type index using weights based on beginning-of-period prices and of a Paasche-type index using weights based on end-of-period prices. The Fisher-type volume index of natural resources has for instance been put forward by Statistics Canada (Islam 2007). While advantageous in many respects, it does not naturally link back to the definition of depletion in difference form. However, it will turn out that there is hardly any difference empirically.

To sum up, in what follows we shall construct a volume index of natural resources $I^{1}$ that tracks the average rate of changes in stocks across natural resources between $t$ and $t-1$. Note that the change in stocks will reflect both increases in stocks (e.g. due to discoveries) and decreases in stocks (e.g. due to extraction), thus the index will be net of discoveries.

$I^{t}=\sum_{i} \frac{\bar{p}_{i}^{t} X_{i}^{t}}{\sum_{i} \overline{p_{i}^{t}} X_{i}^{t-1}}$

A value $I^{t}$ that is less than unity signals that, on average, and valued on a market basis, the natural resource base is declining during period $t$. It is also clear that the measurement of asset prices is key for the construction of the index. In this respect it is again observed that the use of SNA market prices of resources in the ground is the approach that ensures a consistent and meaningful index number is derived.

One notes that the index here is a sub-set of sustainable development indexes that can be found in the literature. Beyond natural resources, the latter typically comprise produced assets, human capital and a varying number of other environmental assets and may adopt different valuation and pricing concepts.

Following the SEEA Central Framework, the depletion of non-renewable natural resources is equal to extractions and hence the quantity index described here should not be equated with a depletion index. However, with data available on removals $\left(S^{t}\right)$ and net additions $\left(D^{t}\right)$ the total rate of change of the volume of assets can be broken down into a rate of removal and a rate of additions by re-formulating (8) as follows:

$I^{t}-1=\frac{\sum_{i} \overline{p_{i}^{t}}\left(X_{i}^{t}-X_{i}^{t-1}\right)}{\sum_{i} \bar{p}_{i}^{t} X_{i}^{t-1}}=\frac{\sum_{i} \overline{p_{i}^{t}}\left(D_{i}^{t}-S_{i}^{t-1}\right)}{\sum_{i} \overline{p_{i}^{t}} X_{i}^{t-1}}=\frac{\sum_{i} \overline{p_{i}^{t}} D_{i}^{t}}{\sum_{i} \overline{p_{i}^{t}} X_{i}^{t-1}}-\frac{\sum_{i} \overline{p_{i}^{t}} S_{i}^{t}}{\sum_{i} \overline{p_{i}^{t}} X_{i}^{t-1}}$. 


\section{APPLICATION TO AUSTRALIAN DATA: VOLUME INDEX OF MINERAL AND ENERGY RESOURCES}

Depending on the country, the components of $I^{t}$ will vary. For instance, uranium or diamonds may constitute important mineral resources in some countries but cannot be found in others. Where a stock is non-existent, the weight attached to it simply becomes zero. Conversely, when a stock is locally abundant and there is no non-local demand, the price for extracted resources from it will be very low or zero which is tantamount to excluding such a stock from the computations for a particular country. For example, given Canada's or Norway's vastness of water resources, the resource rent for water outside hydro reservoirs would be considered zero. ${ }^{13}$ The first step in setting up the index of natural resources is thus constructing time series of the country-specific relevant changes in stocks, measured in physical units. This section develops a volume index of mineral and energy resources for Australia, based on published price and quantity data from the Australian Bureau of Statistics.

\section{Data availability}

The Australian Bureau of Statistics (ABS), as part of its national balance sheets, publishes annual data on quantities and values of the stocks and quantities of production of key natural resources. To date, time series of the relevant value and volume data are available for mineral and energy resources and listed in Table 2. No separate data on $D^{t}$ and $S^{t}$ are currently available so we were not yet in a position to implement the de-composition according to (10).

\section{Constructing the index}

For a particular type of asset, say iron ore, ABS provides the year's closing stock in physical units gigatonnes in the case of iron ore. In the notation used earlier, $X_{i}^{t} / X_{i}^{t-1}$ (i=iron ore, for instance) would be captured as the ratio between the closing stocks of years $t$ and $t-1$. In addition, the ABS balance sheet data give the value of the closing stock in end-year prices. This information is used to value stocks at average prices of the year and to compute the natural resource volume index $I^{t}$. Figure 1 presents the volume index of mineral and energy resources for Australia.

\footnotetext{
${ }^{13}$ While these examples are apt and instructive, it is also recognized that the valuation of water resources, even in water constrained economies, is often problematic with water pricing often only reflecting costs of distribution and very low or negative resource rents. Water valuation is a topic that remains on the research agenda of the SEEA Central Framework.
} 
Table 2: Mineral and energy resources in Australia's national balance sheets

\begin{tabular}{|c|c|}
\hline Asset category (SEEA definition) & Asset type in ABS balance sheets \\
\hline Oil resources & Crude oil \\
\hline Natural gas resources & $\begin{array}{l}\text { Natural gas } \\
\text { Condensate }\end{array}$ \\
\hline Coal and peat resources & $\begin{array}{l}\text { Black coal } \\
\text { Brown coal }\end{array}$ \\
\hline $\begin{array}{l}\text { Non-metallic mineral resources } \\
\text { (excluding coal and peat) }\end{array}$ & $\begin{array}{l}\text { Diamonds } \\
\text { Ilmentite } \\
\text { Magnesite } \\
\text { Rare Earth Elements (REE) } \\
\text { Rutile } \\
\text { Zircon }\end{array}$ \\
\hline Metallic mineral resources & $\begin{array}{l}\text { Antimony } \\
\text { Bauxite } \\
\text { Cadmium } \\
\text { Copper } \\
\text { Cobalt } \\
\text { Gold } \\
\text { Iron ore } \\
\text { Lead } \\
\text { Lithium } \\
\text { Platinum Group Metals (PGM) } \\
\text { Nickel } \\
\text { Silver } \\
\text { Tin } \\
\text { Uranium } \\
\text { Zinc }\end{array}$ \\
\hline
\end{tabular}

Source: SEEA 2012 Central Framework and Australian Bureau of Statistics (2012). Australian National Accounts, Table 62, available at http://www.abs.gov.au/AUSSTATS/abs@.nsf/DetailsPage/5204.0201011 ? OpenDocument. 
Figure 1: Volume index of mineral and energy resources, Australia

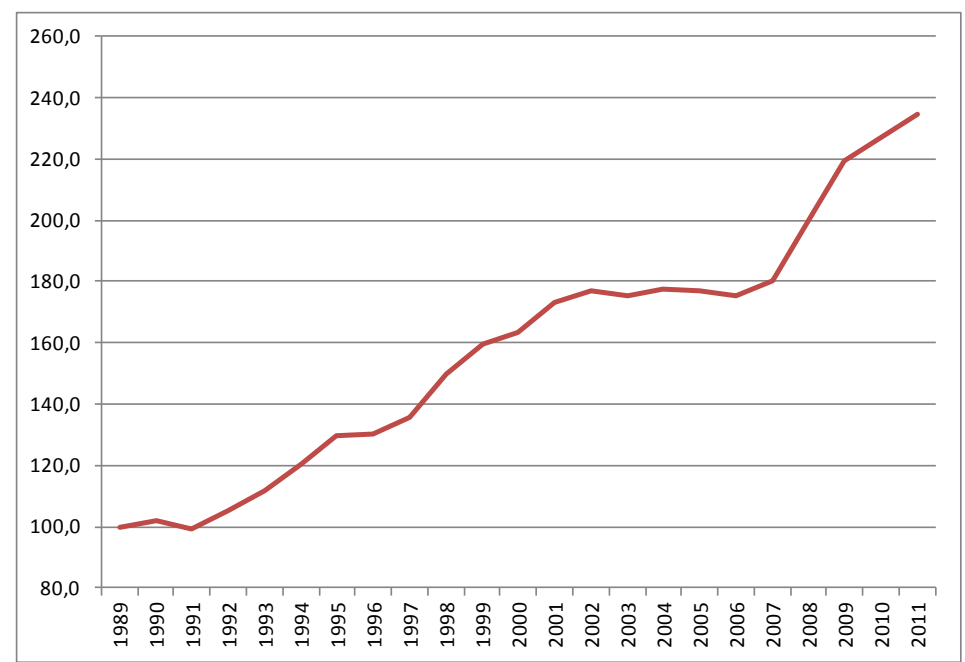

Source: Authors’ calculations based on ABS National Accounts (2012).

The upward trend in Australia's volume index of mineral and energy resources is immediately visible. Despite ongoing extraction of non-renewable resources, their overall volume has increased. This requires that at least for some resources, discoveries exceed removals over the period at hand. (Discoveries in this context reflect the increase in resources due to their recognition as being economically demonstrated, i.e. classified as proven or probable resources). As total mineral and energy resources are finite, the upward trend may revert in the longer run unless new types of natural resources enter the picture. However, for the period at hand, the indicator does not convey a picture of reduced availability of mineral and energy resources.

Linked to earlier discussion on the importance of the choice of prices, it should be recognised that, in practice, it is likely that even for the same resource, there is likely to be a difference in the appropriate price for resources with different likelihoods of extraction. That is, ideally, different asset prices should be used for proven compared to probable resources. Further if differences in prices reflecting different extraction potential can be measured, it may be relevant to extend the boundary for measurement to cover all known deposits not only economically demonstrated resources.

It is also of interest to examine which assets are the main drivers behind the overall trend in the mineral and energy resource volumes. One notes that two elements shape an asset's contribution to the overall index: its share in the overall value of assets (that is the weight by which it enters the index, reflecting its relative economic importance) and the rate by which it grows or depletes. Figure 2 below ranks the various assets by their contribution to the average rate of growth of the volume index over the period at hand. Four of the mineral and energy resources - natural gas, copper, iron ore and nickel - alone account for 3.2 percentage points (that is about $80 \%$ ) of the average annual volume growth of $4 \%$. 
Figure 2: Contribution of different mineral and energy resources to volume index Percentage points of average annual growth 1989-2011, Australia

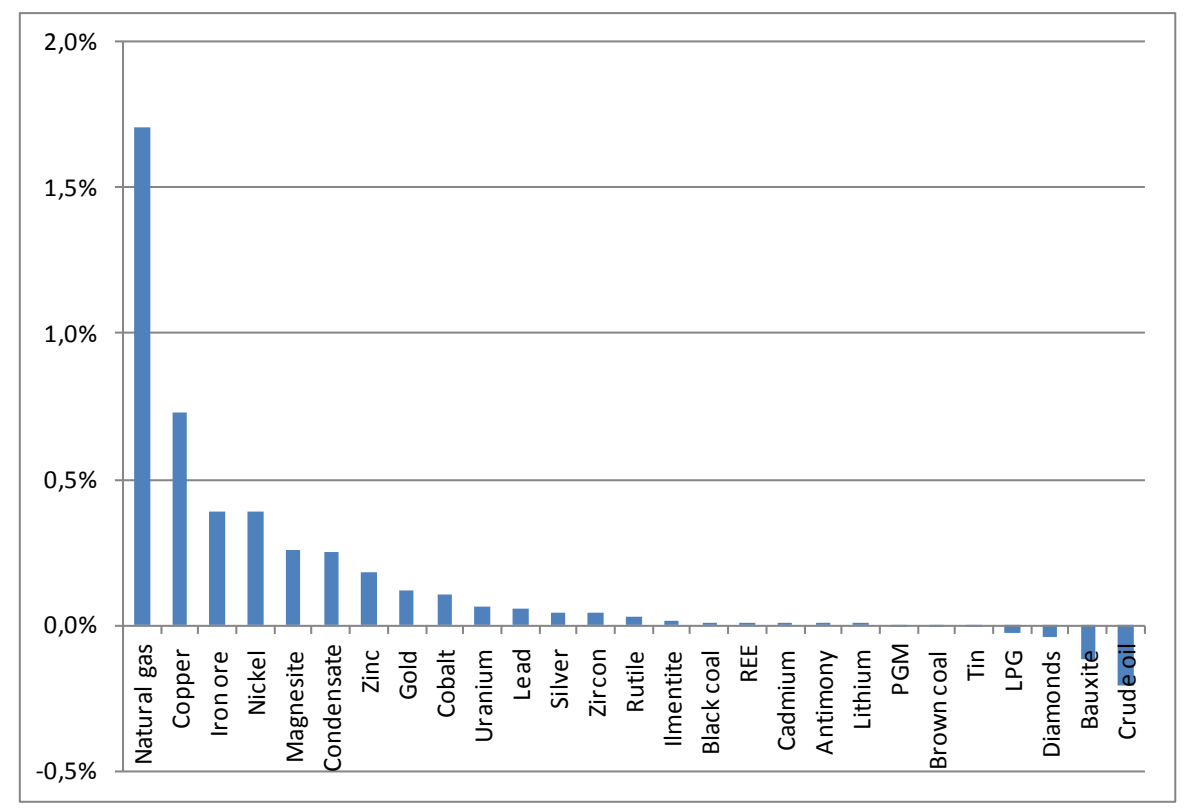

Source: Authors’ calculations based on ABS National Accounts (2012). 
Table 3: Evolution of mineral and energy resources in Australia

\begin{tabular}{|c|c|c|c|c|}
\hline \multirow[b]{2}{*}{ Asset } & \multicolumn{2}{|c|}{ Closing stock 1989} & \multirow{2}{*}{\begin{tabular}{|c|}
$\begin{array}{c}\text { Rate of change } \\
1989-2011\end{array}$ \\
$\%$ per year \\
\end{tabular}} & \multirow{2}{*}{$\begin{array}{c}\begin{array}{c}\text { Average share } \\
\text { in total value of } \\
\text { subsoil assets }\end{array} \\
\% \\
\end{array}$} \\
\hline & Units & Amount & & \\
\hline Antimony & Gigatonnes & 14,8 & $5,9 \%$ & $0,01 \%$ \\
\hline Bauxite & Gigatonnes & 5,6 & $0,3 \%$ & $3,93 \%$ \\
\hline Black coal & Gigatonnes & 51,0 & $-0,2 \%$ & $17,17 \%$ \\
\hline Brown coal & Gigatonnes & 41,7 & $-0,5 \%$ & $0,40 \%$ \\
\hline Cadmium & Gigatonnes & 57,0 & $0,3 \%$ & $0,02 \%$ \\
\hline Cobalt & Gigatonnes & 51,5 & $15,9 \%$ & $0,52 \%$ \\
\hline Copper & Megatonnes & 6,6 & $12,5 \%$ & $6,33 \%$ \\
\hline Diamonds & megacarat (metric) & 457,0 & $-5,9 \%$ & $0,38 \%$ \\
\hline Gold & Tonnes & 1953,4 & $7,2 \%$ & $1,71 \%$ \\
\hline Iron ore & Gigatonnes & 14,5 & $4,0 \%$ & $5,87 \%$ \\
\hline Lead & Megatonnes & 11,1 & $5,6 \%$ & $1,00 \%$ \\
\hline Lithium & Gigatonnes & 254,6 & $2,8 \%$ & $0,02 \%$ \\
\hline Magnesite & Megatonnes & 7,0 & $19,1 \%$ & $0,69 \%$ \\
\hline Ilmentite & Megatonnes & 75,8 & $4,4 \%$ & $0,39 \%$ \\
\hline Rutile & Megatonnes & 9,7 & $4,1 \%$ & $0,53 \%$ \\
\hline Zircon & Megatonnes & 17,5 & $3,8 \%$ & $1,02 \%$ \\
\hline Nickel & Megatonnes & 2,0 & $11,7 \%$ & $5,11 \%$ \\
\hline Crude oil & Gigalitres & 257,5 & $-2,5 \%$ & $13,19 \%$ \\
\hline Natural gas & Billions of Cubic Metres & 994,0 & $4,9 \%$ & $29,02 \%$ \\
\hline Condensate & Gigalitres & 120,5 & $4,8 \%$ & $5,34 \%$ \\
\hline LPG & Gigalitres & 122,0 & $1,0 \%$ & $3,29 \%$ \\
\hline PGM & Tonnes & 23,9 & $-8,5 \%$ & $0,05 \%$ \\
\hline REE & Gigatonnes & 330,0 & $8,2 \%$ & $0,02 \%$ \\
\hline Silver & Gigatonnes & 21,2 & $6,3 \%$ & $0,48 \%$ \\
\hline Tin & Gigatonnes & 179,6 & $-0,4 \%$ & $0,15 \%$ \\
\hline Uranium & Gigatonnes & 471,5 & $4,2 \%$ & $1,59 \%$ \\
\hline Zinc & Megatonnes & 18,4 & $6,2 \%$ & $1,77 \%$ \\
\hline
\end{tabular}

Source: Authors' calculations based on ABS National Accounts (2012).

A comparison of index number formulae

It is well known from the literature on index numbers ${ }^{14}$, that the specific choice of index number formulae is a non-trivial matter in cases whenever prices or quantities of components of an index show large variations over time. In particular, indices will be biased when weights do not reflect some sort of average between periods under consideration. For instance, Laspeyres-type volume indices that use baseperiod weights will tend to overstate volume developments whenever prices and quantities are positively correlated which tends to be the case for natural resource assets (unlike, for instance in the case of private consumption expenditure). This upward bias bears out very clearly in the Australian data as shown in Figure 3. By the same token, a Paasche-type index, based on weights of the current period, understates

\footnotetext{
${ }^{14}$ See for instance Diewert (1987); ILO et al. (2004); Balk (2008).
} 
volume developments in the same circumstances. In contrast, index number formulae with symmetric weights such as the Fisher Ideal Index, the Törnqvist Index and the Marshall-Edgeworth Index put forward in the calculations at hand, all approximate each other rather closely. In particular, the Marshall-Edgeworth index is virtually identical to the Fisher Ideal Index.

Figure 3: Comparison of index number formulae Mineral and energy resources 1989-2011, Australia

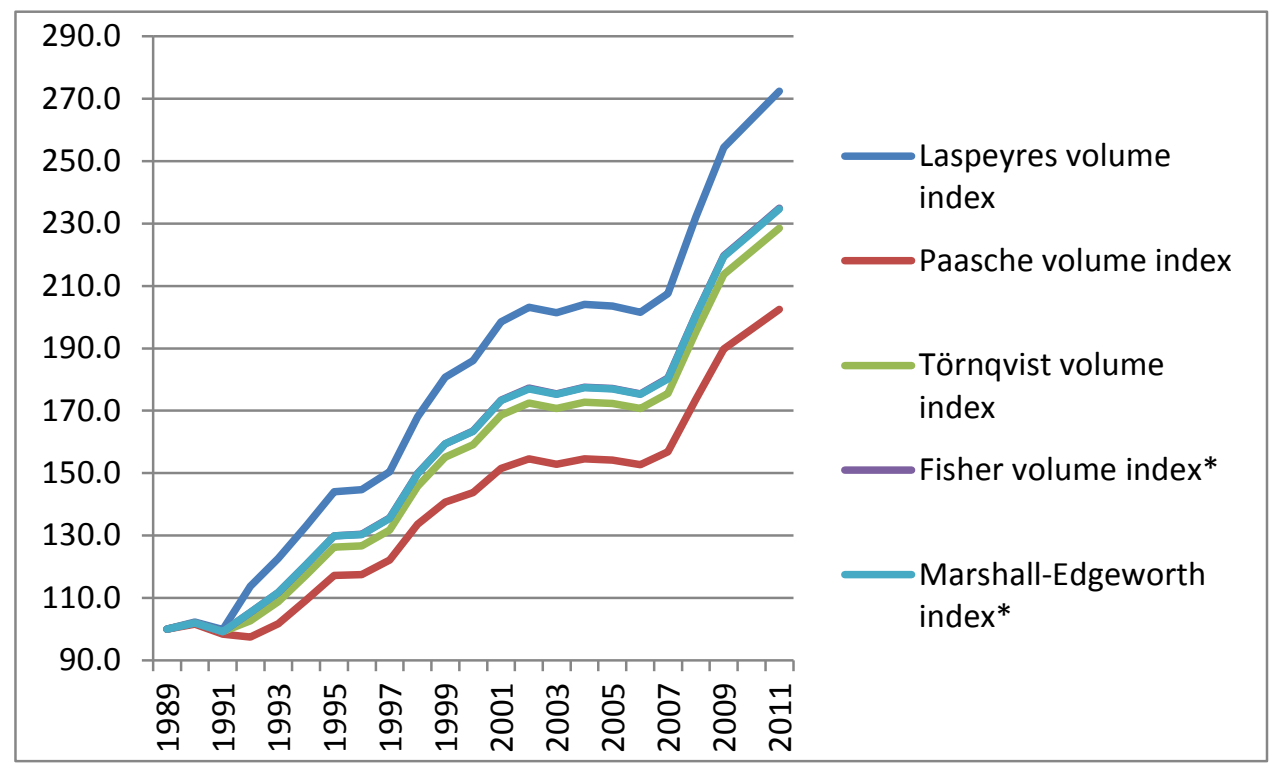

* Fisher and Marshall-Edgeworth Index are virtually identical and not distinguishable on graph.

Source: Authors’ calculations based on ABS National Accounts (2012).

\section{BEYOND THE NATIONAL ACCOUNTS - MEASURING SUSTAINABILITY}

All of the above has been derived within the accounting frameworks of the SNA and the SEEA Central Framework. In this context, stocks and flows of assets are measured from a private rather than from a social perspective. Indeed, the very definition of an asset in the SNA is 'a store of value representing a benefit or series of benefits accruing to the economic owner by holding or using the entity over a period of time" (2008 SNA, paragraph 3.5). The implication is that even though mineral and energy resources are non-renewable, there are additions to the stock that arise because assets are discovered and spring into an 'economic life' by holding the promise of a future income flow. While such additions to the economically viable stock make sense from a private perspective, they are less useful from a societal angle. In particular, an upward trending index of an exhaustible resource seems counter-intuitive from a perspective of measuring sustainability. By definition, the total physical stock of mineral and energy resources is finite and can only decline as a consequence of extraction. We shall now discuss the concept and the information that would be needed to construct an index that better captures sustainability considerations for these resources. 
For this purpose, we shall introduce the physical quantity of the total stock ${ }^{15}$ of a particular resource, $T_{i}^{t}$. It consists of the economically demonstrated resources $X_{i}^{t}$ and the non-economically demonstrated resources, call them $\mathrm{Z}_{\mathrm{i}}^{\mathrm{t}}$. These reflect combinations of lower geological confidence and lower commercial potential, including entirely unknown resources. For simplicity we will refer to these as "unexploited" but the considerations outlined may be refined to take into account different classes of "unexploited" resources. Although estimates may exist on the quantity of unexploited resources, and hence total resources, their full extent is generally unknown. We now have the following accounting relationships:

$X_{i}^{t+1}=X_{i}^{t}+D_{i}^{t}-S_{i}^{t}$

$Z_{i}^{t+1}=Z_{i}^{t}-D_{i}^{t}$

$T_{i}^{t+1}=Z_{i}^{t+1}+X_{i}^{t+1}=X_{i}^{t}+D_{i}^{t}-S_{i}^{t}+Z_{i}^{t}-D_{i}^{t}=T_{i}^{t}-S_{i}^{t}$

Equation (12) repeats the stock-flow relationship of the economically viable stock that governed the derivations in the previous sections. Equation (13) stipulates that the unexploited stock $Z_{i}^{t}$ is reduced by the amount of movements into the economically viable space, $D_{i}^{t}$, for instance from exploitation of shale gas. Equation (14) shows the stock-flow relationship for the total stock whose change corresponds to extractions $S_{i}^{t}$. Thus, the total stock of an exhaustible resource can only decline.

Next, consider the aggregate evolution of total resources, $\Delta T^{t} \equiv T^{t+1}-T^{t}$. As before, because resources are heterogeneous, they need to be price-weighted. It stands to reason that in general, the 'price' by which the undiscovered resource should be valued, is different from the market price $\overline{p_{l}^{t}}$ by which economically viable resources are valued. Let $\overline{\bar{p}}_{i}^{t}$ be such a valuation of $Z_{i}^{t}$. Then:

$\Delta T^{t}=\sum_{i}\left(\bar{p}_{i}^{t}-\overline{\bar{p}}_{i}^{t}\right) D_{i}^{t}-\bar{p}_{i}^{t} S_{i}^{t}$

Several points emerge here. First, the change in total stocks between the beginning and the end of a period, and valued at average prices of the period, equals (the negative of) total extraction plus any valuation difference that arises from quantities of the resource that change from being unexploited to being economically viable. As $\overline{\bar{p}}_{i}^{t} \geq 0$, the value of the change in the stock of total resources will be less than the change in stock of the economically viable resource ${ }^{16}$.

Second, in the special case where, for every type of asset $i$, the social valuation of the undiscovered stocks $\overline{\bar{p}}_{i}^{t}$ equals $\bar{p}_{i}^{t}$, the change in total stocks will simply equal total extraction: $\Delta T^{t}=-\sum_{i} \bar{p}_{i}^{t} S_{i}^{t}$. Conversely, if the social valuation of the undiscovered stock is set to zero, the change in total stocks will equal $\Delta T^{t}=\sum_{i} \bar{p}_{i}^{t} D_{i}^{t}-\bar{p}_{i}^{t} S_{i}^{t}$ and thus coincide with the change of the economically viable stock, all valued at average prices of the period.

Third, to this point our reasoning has been in terms of the level difference of the total stock between the beginning and the end of any period $t$. If $\bar{p}_{i}^{t}$ is known (or set equal to either $\bar{p}_{i}^{t}$ or zero), this permits making a statement of the sustainability of the exploitation of total subsoil assets. Exploitation would be considered sustainable if $\Delta T^{t} \geq 0$ when no substitution is possible with other types of assets such as

\footnotetext{
${ }^{15}$ We owe these considerations to an insightful discussion with Geir B. Asheim in September 2014.

${ }^{16}$ As was mentioned above, there could be different types of unexploited resources - further away or closer to exploitation - and correspondingly, the valuation $\overline{\bar{p}}_{i}^{t}$ could vary accordingly.
} 
produced assets. When substitution is allowed for, the value of $\Delta T^{t}$ would be added to the value of net investment in other assets to judge whether the overall asset base had decreased.

Note that we have made no attempt here to construct a volume index of the total stock, i.e., a relative change in volumes of the total stock. Suppose we had proceeded in the same way as with the volume index $I^{t}$ for the economically viable resources in equation (9). Letting $I_{T}{ }^{t}$ be the corresponding volume index for total resources one would have obtained:

$I_{T}^{t}=\sum_{i} \frac{\bar{p}_{i}^{t} T_{i}^{t}}{\sum_{i} \overline{\bar{p}}_{i}^{t} T_{i}^{t-1}}$

But computation of (16) would require knowledge of the level of each total stock $T_{i}^{t}$ (discovered and undiscovered) which is exceedingly difficult. The only index that can be constructed under the circumstances is a volume index of the change in total stocks, call it $I_{\Delta T}{ }^{t}$ :

$I_{\Delta T}^{t}=\sum_{i} \frac{\bar{p}_{i}^{t} \Delta T_{i}^{t}}{\sum_{i} \overline{\bar{p}}_{i}^{t} \Delta T_{i}^{t-1}}=\sum_{i} \frac{\bar{p}_{i}^{t} S_{i}^{t}}{\sum_{i} \bar{p}_{i}^{t} S_{i}^{t-1}}$

The second expression on the right hand side of (17) has been derived by setting $\overline{\bar{p}}_{i}^{t}=\bar{p}_{i}^{t}$ for simplicity. Thus, (17) indicates whether depletion of total stocks has accelerated or decelerated which is a different statement from the index $I_{T}{ }^{t}$ in (16) that tracks the volume of the level of the total stock.

In conclusion, statements about sustainability require tracking the evolution of the total stock of assets, economically viable and non-exploited. Observations on the change in total stocks are sufficient to derive statements on period-by period sustainability, but only if one is ready to make simplifying assumptions about the price of undiscovered resources. No index of the evolution of the aggregate volume of the total stock can be constructed, however, as this requires weighting the evolution of individual stocks by their share in the total value of stocks and the latter are generally unknown. 


\section{CONCLUSION}

The measurement and analysis of national wealth is a fundamental requirement in the assessment of the sustainability of economic growth and national well-being. This paper focuses on the issue of the valuation of natural resources. To do so it builds on the work undertaken in the context of the System of National Accounts and on the recent release of international statistical standards for environmental accounting - the SEEA Central Framework.

There are a number of key messages that emerge from the paper. First, it is clear that work at national level on the regular measurement of the value of natural resources is still in its infancy despite the general approach having been in place for many years. Second, while the general approach has been in place, it has often been applied in a manner that is inconsistent with the valuation approaches used for measuring other parts of the economic asset base thus limiting the meaningfulness of aggregation in a balance sheet context. What is confirmed in this paper is that a natural resource stock should not be valued using the unit resource rent as the price of the resource. Rather the price of the resource should reflect its in situ (before extraction) price. This approach ensures a consistency between the accounting for changes in the physical stocks of the resource and the valuation of those changes.

Third, by aligning the accounting in physical and monetary terms it is possible to construct standard volume and price indexes of natural resources. Further, it is straightforward to develop measures of the capital services of natural resources. In volume terms, for a non-renewable resource, this will equal the extracted amounts. Extending national estimates of multi-factor productivity to take into account the contribution of natural resources is thus possible.

Fourth, while the analysis of wealth and sustainability are inter-twined, it is important to understand the differences. In particular, statements about sustainability require tracking the evolution of the total stock of resources, economically viable and unexploited. Then, observations on the change in total stocks are sufficient to derive statements on period-by period sustainability, if one is ready to make simplifying assumptions about the price of unexploited resources. However, unlike assets that are recognised in balance sheets, no index of the evolution of the aggregate volume of the total stock can be constructed, as this requires weighting the evolution of individual stocks by their share in the total value of stocks and the latter are generally unknown.

Overall, this paper demonstrates the potential to align more explicitly the bodies of work on capital theory, index number measurement and growth accounting on the one hand, and valuation and measurement of natural resources on the other. From a practical accounting perspective this alignment should aid in the implementation of broader measures of wealth at national level which are required for policy and analysis. 


\section{REFERENCES}

Al-Attar A., Alomair O. (2005): Evaluation of Upstream Petroleum Agreements and Exploration and Production Costs. OPEC Review

Australian Bureau of Statistics (2012). Australian National Accounts, Table 62, available at http://www.abs.gov.au/AUSSTATS/abs@.nsf/DetailsPage/5204.02010-11?OpenDocument.

Brandt, Nicola, Paul Schreyer and Vera Zipperer (2013); „Measuring Productivity with Natural Capital“; OECD Economics Department Working Paper 1092; available under http://www.oecdilibrary.org/economics/oecd-economics-department-working-papers_18151973

Balk, Bert (2008); Price and Quantity Index Numbers; Cambridge University Press; Cambridge Mass.

Bennet, T. L. (1920); ’The Theory of Measurement of Changes in Cost of Living”; Journal of the Royal Statistics Society 83: 455-462.

Dasgupta, Partha (2009); “The Welfare Economic Theory of Green National Accounts”; Environ. Resource Economics 42, pp. 3-38.

Diewert, W. Erwin (1974), "Intertemporal Consumer Theory and the Demand for Durables", Econometrica 42, 497-516.

Diewert, W. Erwin (1978); “Superlative Index Numbers and Consistency in Aggregation”; Econometrica, Vol. 46, pp. 883-900.

Diewert, W. Erwin (1987); "Index Numbers”; The New Palgrave: A Dictionary of Economics; edited by J. Eatwell , M. Milgate and P. Newman; Palgrave MacMillan.

Diewert, W. Erwin (2005); “Index Number Theory Using Differences Rather Than Ratios”; The American Journal of Economics and Sociology, Vol. 64, No. 1; pp. 311-360.

Diewert, W. Erwin and Chihiro Shimizu (2013); “A Conceptual Framework for Commercial Property Price Indexes”; Discussion Paper 13-11, School of Economics, The University of British Columbia; http://www.economics.ubc.ca/files/2014/04/pdf_paper_erwin-diewert-13-7-residential-property.pdf

Diewert, W. Erwin and Paul Schreyer (2008); “Capital Measurement”; New Palgrave Dictionary of Economics.

European Union, International Labour Organization, International Monetary Fund, Organisation for Economic Co-operation and Development, United Nations Economic Commission for Europe, The World Bank (2013); Handbook on Residential Property Prices Indices (RPPIs); available under http://epp.eurostat.ec.europa.eu/cache/ITY OFFPUB/KS-RA-12-022/EN/KS-RA-12-022-EN.PDF 
European Commission, IMF, OECD, World Bank, United Nations (2009), 2008 System of National Accounts, New York, United Nations; Available under http://unstats.un.org/unsd/nationalaccount/sna2008.asp

Edgeworth, Francis Y. (1925); Papers Relating to Political Economy, Vol. 1, New York.

Edens, Bram and Lars Hein (2013); “Towards a consistent approach for ecosystem accounting”; Ecological Economics 90, pp. 41-52.

Fox, Kevin J. (2005); A Method for Transitive and Additive Multilateral Comparisons: A Transitive Bennet Indicator; Journal of Economics; Vol. 87 (2006), No. 1, pp. 73-87.

Hotelling, Harold (1931): The Economics of Exhaustible Resources. Journal of Political Economy, Vol. 39, pp. 137-175.

ILO, IMF, World Bank, OECD, UN (2004); Producer Price Index Manual - Theory and Practice; Washington D.C., International Monetary Fund.

Islam, Kazi (2007); “Canada’s natural resource wealth at a glance”; EnviroStatistics, December, Statistics Canada.

Jorgenson, Dale W. (1963), “Capital Theory and Investment Behavior,” American Economic Review, 53(2): 247-59.

Jorgenson, Dale W. and Zvi Griliches (1967), ”The Explanation of Productivity Change,” Review of Economic Studies, 34(99), 249-280.

Jorgenson, Dale W., J. Steven Landefeld, and William D. Nordhaus, (eds) (2006), A New Architecture for the U.S. National Accounts, Chicago, University of Chicago Press, 13-112.

Landefeld J.S., Hines J.R. (1985), National Accounting for Non-Renewable Resources in the Mining Industries. Review of Income and Wealth, Vol. 31, No. 1, pp. 1-20

Livernois, John (2008), On the Empirical Significance of the Hotelling Rule, Review of Environmental Economics and Policy, Vol. 3, No. 1, pp 22-41.

Marshall, Alfred (1887); “Remedies for Fluctuations of General Prices”; Contemporary Review, Vol. 51, p. 355-75.

OECD (2011); How’s Life? 2011: Measuring Well-being, Paris.

OECD (2013); How’s Life? 2013: Measuring Well-being, Paris.

Piketty, Thomas and Gabriel Zucman (2013); "Capital is back: Wealth-Income Ratios in Rich Countries 1700-2010”; Quarterly Journal of Economics.

Sefton, James A. and Martin R. Weale (1996), “The Net National Product and Exhaustible Resources: The Effects of Foreign Trade,” Journal of Public Economics 61, 21-47.

Stiglitz, J., A. Sen and J-P. Fitoussi (2009); Report by the Commission on the Measurement of Economic Performance and Social Progress; online document http://www.stiglitz-senfitoussi.fr/documents/rapport_anglais.pdf 
United Nations, European Commission, Food and Agriculture Organization of the United Nations, International Monetary Fund, Organisation for Economic Co-operation and Development, The World Bank (2014); System of Environmental-Economic Accounting 2012 Central Framework, New York, United Nations

United Nations, European Commission, Organisation for Economic Co-operation and Development, The World Bank (2013); System of Environmental-Economic Accounting 2012 Experimental Ecosystem Accounting, white cover version. Available at http://unstats.un.org/unsd/envaccounting/eea_white_cover.pdf

World Bank (2011), The changing wealth of nations, Washington DC, The World Bank. 
www.oecd.org/greengrowth 